Grand Valley State University

ScholarWorks@GVSU

10-1989

\title{
Trials and Tribulations: Authors' Responses to Censorship in Imperial Germany, 1885-1914
}

Gary D. Stark

Grand Valley State University, starkg@gvsu.edu

Follow this and additional works at: https://scholarworks.gvsu.edu/hst_articles

Part of the History Commons

\section{ScholarWorks Citation}

Stark, Gary D., "Trials and Tribulations: Authors' Responses to Censorship in Imperial Germany, 1885-1914" (1989). Peer Reviewed Articles. 9.

https://scholarworks.gvsu.edu/hst_articles/9

This Article is brought to you for free and open access by the History Department at ScholarWorks@GVSU. It has been accepted for inclusion in Peer Reviewed Articles by an authorized administrator of ScholarWorks@GVSU. For more information, please contact scholarworks@gvsu.edu. 


\title{
Trials and Tribulations: Authors' Responses to Censorship in Imperial Germany, 1885-1914
}

\author{
Gary D. Stark \\ University of Texas, Arlington
}

I

In Thomas Mann's famous short story of 1903 about the artist's problematic relation to bourgeois society, the aspiring young writer Tonio Kröger, after an absence of thirteen years, returns to his hometown for a brief visit. There he is confronted by a policeman who, suspecting Kröger to be a swindler wanted by the law, questions him about his identity and occupation. Kröger, although recognizing that this guardian of civic order is within his rights, is nevertheless reluctant to reveal who he is. Unable to provide the requisite identity papers, he finally shows the policeman proof-sheets of a story of his that is about to be published. The officer is not entirely convinced the young writer is not the wanted criminal, but in the end he lets the matter drop and allows Kröger to leave the country. This unsettling confrontation with a representative of the German state drives home to Kröger his social isolation, his uneasy existence between two seemingly incompatible worlds: that of his bohemian artist friends, who regard him as a bourgeois, and that of the bourgeois, who try to arrest him. It also reinforces his long-standing aversion to his hometown and his eagerness to return soon to his self-imposed exile in the more hospitable south.

Tonio Kröger's situation is symbolic of that of many fin de siècle German writers. As numerous scholars have noted, many late nineteenth and early twentieth century German literati shared three distinct but interrelated characteristics: an acute self-consciousness; a sense of alienation from bourgeois society; and an "unpolitical" withdrawal from the pressing social and political problems of the day. During the nineteenth century, but especially since Nietzsche, German writers became increasingly conscious of their existence as a distinct, semi-independent social group and were increasingly preoccupied with questions about the role of art in the modern world, the unique nature of 
the artistic calling, the artist's position and function in bourgeois society, and the artist's responsibilities to Geist. At the same time, their intense concern with (and at times glorification of) the artist's special calling created in many German writers a growing sense of separateness from the rest of society. Authors, particularly in the fin de siècle era, frequently felt isolated and alienated from "normal" life; because of their unique artistic temperaments and their special, "higher" calling, many of them felt like outsiders who did not belong to bourgeois society. Frequently, this sense of social isolation resulted also in a conscious withdrawal from the real world, especially the world of power and politics. Perceiving the inner world of Geist rather than the external world as the authentic one, and regarding active involvement in social or political issues as incompatible with or even harmful to their "higher" artistic calling, German writers generally scorned political engagement. Many escaped from what they perceived as oppressive social or political conditions by retreating into the "unpolitical" realm of the spirit. But this unpolitical disdain for issues of power and politics had serious political consequences. Their "inner emigration" led many into resignation about the existence of social evil and political injustice; the result was widespread political fatalism concerning the possibility of sociopolitical change or silent acceptance of the status quo. ${ }^{1}$

As the story of Tonio Kröger illustrates, external challenges, especially from authority, can play a significant role in the process by which individuals or groups clarify their self-image, define their social role, and choose their political responses, for such challenges often stimulate self-reflection. Hermann Hesse, a contemporary of Thomas Mann, reached much the same conclusion: reflecting on the writer's calling shortly before the First World War, Hesse observed that "the Literati, exactly like every physician or judge or civil servant, are instructed and enlightened (aufgeklärt) about the essence and character of their vocation through the kinds of demands that others make on them."

Among the many external challenges faced by fin de siècle German writers, one of the most pervasive and potentially serious to their careers was that of censorship. German writers in the imperial era had to contend with a more extensive, and less tolerant system of censorship than their counterparts in France or Britain. Although the Imperial Press Law of 1874 guaranteed freedom of the press in Germany and abolished preventive or prior censorship (i.e., the need to obtain official approval before a work could be published), the Imperial Criminal Code still permitted local prosecutors to confiscate, and with court approval to destroy, any printed matter that violated the laws against obscenity, blasphemy, or lèse majesté. Under certain conditions, authorities could also prosecute the author of such works; if convicted, the defendant could be fined up to 1,000 marks or imprisoned for up to five years. In contrast to the press, the public stage in Germany was still subject to prior censorship in the imperial era, for in most German cities theater directors had to obtain prior 
police approval for each drama that was to be performed publicly. Police had the right to ban any drama they believed would endanger public peace or security or would threaten the existing moral or political order. While it is true that France, Great Britain, and other nations also had laws prohibiting obscene or blasphemous publications, the laws in Germany were generally applied more stringently (e.g. authors, not merely publishers or booksellers, could be prosecuted), and the German penalties tended to be more severe. As for the public stage, France abolished its system of theater censorship in 1905-06, although Britain, like Germany, required that all new stage plays be submitted for prior state approval. British theater censorship, however, was far more lenient than its German counterpart: during the decade 1891-1900, for example, only twenty-two plays were banned in all of Britain, while during that same period, 157 works were banned in the city of Berlin alone! ${ }^{3}$ Censorship, in short, posed a far more significant and frequent threat to writers in late nineteenth century Germany than it did to writers in either France or Britain. While it is true that, in the end, the success of German censors in suppressing certain types of artistic products fell far short of their intentions, ${ }^{4}$ this seldom deterred them from trying, and it did little to diminish the anger, frustration, and sometimes psychological trauma involved for the authors who ran afoul of the censors.

Censorship is, in the broadest sense, an attempt by society (through its authorized agents, the governing authorities) to control artists by defining the limits of artistic activity and by isolating or punishing artists who violate those boundaries. It therefore reveals a good deal about what a society considers the proper role of art and artists to be. For artists, in turn, the experience of being censored can significantly affect their self-image, their vocational identity, their perception of their place within society, and their level of political consciousness and engagement. This essay will examine how the experience of being censored affected the views of several German authors of the imperial era concerning their calling as writers and their relation to German society and/or the imperial authorities.

Between 1885 and the First World War, approximately twenty German authors of serious literary works, including such figures as Conrad Alberti, Hermann Bahr, Hugo Ball, Klabund, and Ludwig Thoma, were prosecuted for what they had written. Of these, roughly one-fourth were acquitted, another one-fourth were fined, and the rest were imprisoned for anywhere from two weeks to one year. Scores of other authors - some of them major figures such as Gerhart Hauptmann, Paul Heyse, Arthur Schnitzler, and Carl Sternheim, some relatively obscure and now forgotten - saw at least one of their works temporarily or permanently confiscated, or had the public performance of one or more of their dramas prohibited by the police. Many of the authors who experienced censorship, especially those for whom censorship meant merely 
the banning of one of their dramas from the public stage, have left little or no indication of how that encounter affected them and their attitudes toward German society. But for others, especially those who were actually prosecuted, the experience was a significant one that they discussed in print or in private diaries and correspondence. We know little about how the former group responded to censorship, but we do know something about how the latter group did, and it is on this group that my study will necessarily concentrate.

While it comes as no surprise that the experience of censorship generally aggravated these authors' sense of estrangement from German society, the extent of their alienation, the form it took, and the conclusions they drew from it varied greatly. I have identified three distinct types of alienation exhibited by censored authors in imperial Germany: "radical alienation," "ambivalent alienation," and what I shall call for lack of a better term, "internalized alienation." Radically alienated authors, because of the antipathy they perceived in Germany toward their own work and toward writers in general, completely severed their ties with German society to preserve their artistic integrity. Authors who internalized their alienation, despite certain resentments they may have harbored toward the imperial order, never abandoned their hope of becoming reconciled with their society, even if this meant sacrificing some artistic autonomy or even renouncing their own work. The ambivalently alienated seemed torn between these two poles.

\section{II}

The best example of an author impelled into radical alienation by censorship was Oskar Panizza (1853-1921). In the 1890s, six different stories, dramas, or satirical writings of Panizza's were confiscated by police; for one of these works, Das Liebeskonzil (1894), Panizza was convicted for blasphemy and served 1 year in a Bavarian prison. ${ }^{6}$ Panizza, one of the earliest, most active, and most eccentric members of Michael Georg Conrad's circle of Munich naturalists, the Gesellschaft für modernes Leben, believed adamantly in the inner-directed artist's absolute autonomy from external constraints. His experience with censorship and his incarceration helped transform him from a critic to a hostile enemy of German society.

Prior to his confrontation with the state, Panizza had argued that artistic talent and genius bordered closely on what society labeled "abnormal" or "insane." To Panizza, all creative thought was the result of an individual's unique, mysterious demonic illusions. Artists must follow their own inner daemon, regardless of the consequences; they must never compromise their convictions, even when these appeared to conflict with external "reality." Even though they might be labeled abnormal or even regarded as insane by others, artists must always place their deepest inner convictions - their "holy spirit" 
- above society's arbitrary and relative norms. To Panizza, true artists were thus martyrs; they were inevitably condemned and persecuted by society, which insisted on imposing on them its own meaningless standards. ${ }^{\text {? }}$

After his 1895 trial and conviction, Panizza proclaimed even more passionately the eternal irreconcilability of artists and society. He spoke satirically - although with profound earnestness - of the "poet's divine right" (Gottesgnadentum des Dichters). ${ }^{8}$ Poets were endowed with a special inspiration and ability to express their insights, he believed; this gift was bestowed only on artists, and it both enabled and compelled them to follow their inspirations and convictions regardless of all social considerations or legal constraints. According to Panizza, the burden artists bore was a heavy one, and their special calling entailed suffering and constant struggle; they were answerable only to a higher authority and could not be absolved from their duties by any man, state, prosecutor, parliament, or nation. Society, however, refused to recognize the poet's calling; and because poets, in turn, refused to accept society's arbitrary norms, society tried to stifle poets and prevent them from expressing their inner, divinely-inspired convictions. If poets insisted on following their convictions, society either imprisoned them, forced them into exile, or declared them insane. But those whom society regards as insane are tolerated and left alone. To Panizza, then, the insane asylum was perhaps the only feasible alternative open to the artist within society. Although being declared insane meant social isolation, it meant also complete spiritual freedom. Panizza satirically suggested that until society was ready to recognize their right of self-expression and to heed their truths, artists should petition parliament for the freedom and protection offered by legal insanity. In another work, he advised the guardians of the state to declare all freethinkers criminal psychotics and to confine them to a huge asylum (he suggested the Pfalz); this, he reasoned, would both protect them from future social persecution and at the same time permit society to preserve its precious norms. ${ }^{9}$

Panizza's imprisonment irrevocably estranged him from the German social and political order and radicalized his political outlook. He emerged from prison a deeply embittered enemy of his native land and immediately repudiated it in the most decisive and vehement manner possible.

While in prison, Panizza reflected on German society's brutal treatment of writers and voiced his anger in caustic satirical works. In Ein Jahr Gefängnis, his jailhouse diary, he spoke of a "land of the non-promulgation of thoughts" (Gedankennichtverlautbarung) in Northern Europe where the climate was so frigid that most inhabitants had learned to breathe only through their noses. For those who exhaled through their mouth found that their breath immediately froze into a solid icicle protruding from their lips. Police would then quickly appear, grab hold of the frozen objects, and drag the unfortunates before a court, where they were sentenced to up to 8 years in prison, depending on the length 
of the icy evidence. Thus the natives were extremely careful not to breathe their thoughts out through their mouths, where these could be heard, seen, and seized by the police - indeed, they had learned that even talking about breathing was dangerous. ${ }^{10}$ In another of his prison works, Panizza referred to the "buryingalive" (Lebendigbegraben) of poets, writers, journalists, and artists in late nineteenth century Germany and lamented that no voices cried out in protest. ${ }^{11}$

During his incarceration, Panizza also reflected more deeply about Germany's social and political system and drew radical conclusions. In the early 1890 s, he had briefly tried to help form an alliance between Munich's avantgarde naturalist writers and the city's Social Democratic working class. ${ }^{12}$ In prison, Panizza came into closer contact with members of the proletariat and criminal underclass, and his feelings toward them became more ambivalent. One the one hand, he developed a grudging admiration of the Social Democratic movement for its idealism, but on the other, he was repelled by what he saw of this uneducated Lumpenproletariat. In his prison writings, he levelled a strong critique against the entire Bavarian criminal justice system, and radically reinterpreted the relation between the individual and the state. Panizza became convinced that the great questions of the future would be the status of workers, the problem of individual liberation, and the destruction of old authorities, especially the monarchy. He embraced a vague anarchism and developed a deep interest in and admiration for earlier political martyrs like Karl Sand. ${ }^{13}$

As a result of the punishment imposed on him by society, it became clear to Panizza that life for him as a writer in Germany was impossible. At his trial, he had already explained to the court why he published his Das Liebeskonzil in Switzerland: "Every German author, at one time or another, has something on his heart that he can't have printed in Germany, and then he goes abroad." 14 While in jail, he wrote that flight abroad was one of the three fates open to a freethinker who wanted to express himself in Germany (the other two being imprisonment and insanity). ${ }^{15}$ Fearing the social isolation he would encounter upon his release from prison - society would scorn him as a criminal, and even his embarrassed friends would avoid contact with him - he decided he must "leave the land of asphalt before it burns the soles of my shoes."16 "I always saw," he later noted, "that those who expressed new ideas had to flee, and later, even if only through their writings, they were brought back. That suits me perfectly." ${ }^{17}$ So upon his release from prison in 1896, Panizza renounced his Bavarian citizenship and resettled first in Zurich, then in Paris.

Once safely beyond the German border, Panizza poured out his hatred for the social climate and political system of his homeland. In his collection of vitriolic anti-German poems Parisjana (1899), composed during his Paris exile, he denounced Germans as a backward, arrogant, smug, and hopelessly servile people while praising France as Germany's free, rational, enlightened antithesis. ${ }^{18}$ Germans' spießbürgerlich intolerance and their hostility to artists and other 
intellectuals came under particular attack. In Panizza's eyes, Germany was "a land of barbarians" populated by "a pack of horses" interested only in their potatosacks and who sought at every turn to "strangle the muses." In Germany, he charged, "one's Best, what one calls Soul," is treated en canaille. "Don't throw pearls to these sows,/ no verses to these barbarians" he warned. ${ }^{19}$ The antimonarchical, anarchist leanings Panizza had developed in prison now emerged with full revolutionary force in these poems. He denounced all bailiffs, police, executioners, and other guardians of public order and called upon the German people to rise up against their tyrannical rulers - especially Wilhelm II, whom he called a "mad dog" and "the public enemy of mankind and culture." 20

The publication of Panizza's vitriolic Parisjana prompted the German authorities not only to confiscate the work for slandering the Kaiser, but also to issue another warrant for Panizza's arrest. To force the exile to return, they also seized all his financial assets in Germany, which he had been using to support himself. Panizza's latest confrontation with the state isolated and alienated him still further, this time from his family, which repudiated him as an embarrassment and sought to have him declared mentally incompetent. This final break with his family so psychically shattered Panizza he considered suicide; thereafter he bitterly blamed the Munich police and Bavarian government for splitting apart his family and destroying his ties with them. ${ }^{21}$ Broken and financially destitute, he returned to Bavaria in 1900, was immediately placed under psychiatric observation, and at the strong urgings of his family, was declared mentally incompetent. ${ }^{22}$ A few years later he was committed permanently to an asylum, where he spent the final sixteen years of his life totally insulated from the society he despised. Of the three fates he once said were open to a writer in Germany - imprisonment, exile, insanity - Panizza had experienced them all.

No other censored author became so totally isolated and radically alienated from German society as did Panizza. Only the young Berlin naturalist Hermann Conradi (1862-1890), who was indicted for obscenity and blasphemy in 1889 over his novel Adam Mensch, merits comparison. ${ }^{23}$ Like Panizza, Conradi believed the artist and bourgeois society were natural enemies. Before his clash with the censor, Conradi had preached that if the creative impulse was not to be thwarted and weakened, artists must be allowed to follow the spontaneous impulses of their souls, even if these conflicted with the rules and norms society had laid down for the preservation of social order. Any potential social harm that might result from the artist's complete freedom would be more than offset, Conradi believed, by the rich artistic creations that would ensue. Conradi believed that to produce pure, natural and original art, creative artists must insulate themselves from the influences of bourgeois society, avoiding normal bourgeois occupations so as not to fall under the influence of those social institutions and traditions that were products of "the herd instincts of the 
masses." ${ }^{24}$ After he was indicted, Conradi's disdainful scorn toward the guardians of the bourgeois order only deepened. He regarded the authorities' actions as "silly and childish" and he adopted a stand-point "rooted firmly in the a priori sovereignty of art." 25 The young writer considered his novel "a first-rate psychological-artistic-cultural document, even if 10,000 old or 'young' embalmed herrings ... bite out their moral teeth on it." ${ }^{26}$ Even though he faced up to three years in prison if convicted, Conradi professed not the slightest concern over what "old fogeys" like the state prosecutor thought of him or his work, and he refused "to dance to the whims of those gentlemen." At his preliminary court hearing, he later boasted, he had behaved with "unbelievable self-assurance, superiority, and casual sovereignty."27

Conradi died in the midst of his obscenity trial, thus cutting short any further development of his nascent radical alienation. Had he lived, he would almost certainly have been convicted and sentenced to several months in prison. There seems every reason to believe that such a fate would have only deepened his hostility to bourgeois society and alienated him further from it.

\section{III}

A second group of authors experienced what I call ambivalent alienation as a result of undergoing censorship. Like Panizza, they saw in the very institution of censorship proof of German society's lack of respect for the value of literature and its disdain for writers, and they were tempted to emigrate, like he had, to less hostile settings abroad. Yet in the end, the forces binding these writers to their native society proved stronger than the forces repelling them from it.

More importantly, ambivalently alienated authors exhibited an unusually defensive reaction to the experience of censorship. Their clash with the authorities shook their self-confidence or produced in them a crisis of identity, which in turn led to a critical new self-awareness. Of course they never admitted the censor's charges against their work were justified. But while publicly proclaiming their innocence and defending their work, privately they expressed misgivings about their previous assumptions and values, they reproached themselves for their literary excesses, and they resolved to redirect their literary efforts. The two best examples of ambivalent alienation among censored authors are Frank Wedekind (1864-1918) and Richard Dehmel (1863-1920).

After Wedekind had served seven months in prison for lèse majesté in $1899,{ }^{28}$ been twice indicted but acquitted for obscenity in $1904-06,{ }^{29}$ and seen several of his dramas confiscated or banned from the public stage, ${ }^{30}$ he published two essays on censorship in which he asserted that literary censorship in Germany was a product of that society's lack of respect for the arts and of the German bureaucracy's disdain for authors. Indeed, Wedekind claimed not 
to know which was worse: bourgeois society's general disinterest in literary life and its blind acquiescence to police harassment of writers, or the fact that only the police took art seriously in Germany, in the sense that they vastly overestimated its power to corrupt society. "After all is said and done," Wedekind complained, "to the German authorities, a German writer is merely a dumb child. ..." 32 The banning of works like his Die Büchse der Pandora and Totentanz, while comparable works by English or Russian authors were passed, had made Wedekind realize "what a singularly thankless honor it is to be a German [writer] in Germany." 33

In the midst of his first serious encounter with the censor, Wedekind emigrated briefly, but ultimately found it an unsatisfactory solution. Facing up to a year's imprisonment for lèse majesté in 1898, Wedekind first fled to Zurich, then to Paris, where he spent time with his exiled friend Oskar Panizza. But after eight months in exile, Wedekind decided to "make my peace with the German Reich" and returned to face his punishment. "I "I have almost learned to love Germany," he wrote a friend shortly before he repatriated from Paris. ${ }^{35}$

Besides leading him to work through some of his ambivalent feelings toward Germany, Wedekind's brushes with censorship also prompted a series of critical self-reassessments. After he was indicted for lèse majesté, Wedekind found it painful to admit that he had written the satirical poem in question not out of political conviction, but for simple material gain. One reason he fled to Switzerland after his indictment, he told a friend, was to avoid having to testify that in composing the poem, he had ignored his own convictions and moral beliefs. To have admitted that in a public forum, he confessed, "would have been a disgraceful humiliation for me." ${ }^{36} \mathrm{~A}$ few years later, when a Berlin court ruled the first edition of his Die Büchse der Pandora obscene and ordered it destroyed, Wedekind rewrote portions of the drama and published a new edition. In the new preface, he acknowledged that the trial over the earlier version had produced a far closer assessment of the play's ethical and artistic qualities than it would otherwise have received. Removing all those passages to which the court had objected, Wedekind confessed, had actually improved the drama both ethically and artistically. ${ }^{37}$

But even the revised version of Die Büchse der Pandora was banned from the public stage. To answer those who condemned his work because of its supposed lack of "ethical sincerity," Wedekind composed an autobiographical one-act play entitled Die Zensur. Through the character of Buridan (who is a transparent self-portrait of himself), Wedekind justified his art and appealed for the release of Die Büchse der Pandora. At the same time, however, there is in Die Zensur a rather sympathetic portrayal of the censor's viewpoint, represented by the churchman Prantl. Through Prantl, Wedekind appears in Die Zensur to be reproaching himself for three serious artistic and ethical shortcomings: First, that his art contains an element of emotional exhibitionism; like other modern 
artists, he displays to all the world (and in return for money!) all his darkest personal secrets and those inner emotional struggles that are best worked through in privacy. Second, that he lacks concern for the ethical consequences of his art and its effect upon people's lives. Third, that in his portrayals of human pain, misfortune, and despair, he displays a certain Schadenfreude, and encourages it in others. Buridan/Wedekind, the censor in the play charges, lacks empathy and any sense of brotherly love for his destitute characters. After the writer Buridan has proclaimed his basic human goodness, the censor Prantl tells him:

Your 'human goodness' would never stop your Reason from writing a theater piece about some unfortunate creature you have just trampled into the ground. That is the most grotesque aspect of your performances: everything is the most living reality. Instead of plays, you create casualties. If a man dies by you, then it's just a human life gone; no trace of any spiritual participation. And whenever possible, you even boast of these abominations. Annihilated human lives are the milestones of your life's path.... One sits before your art like imperial Rome sat before the gladiator's battles and the persecution of the Christians. Baiting wild beasts of prey are the summits of what you call art. ${ }^{38}$

Since Buridan/Wedekind makes no effort to refute these charges raised by Prantl, readers are left with the impression that Wedekind implicitly recognized at least some validity in the accusations of his critics and censors.

Richard Dehmel, another ambivalently alienated author, was twice indicted for obscenity and blasphemy, but acquitted both times. ${ }^{39}$ Because of a legal technicality, he narrowly missed being indicted a third time, and would have almost certainly been convicted on that occasion; as a result of that incident, a court ruled that a collection of his poems was obscene and blasphemous, and ordered it destroyed. ${ }^{40}$

After his second censorship trial in 1900, Dehmel complained bitterly that the writer's path in Germany was strewn with more thorns than roses and he too toyed with the idea of leaving. Yet after a brief trip abroad, he admitted his "stupid German heart" got the better of his "clever, cosmopolitan head" and he returned eagerly to his homeland. Although still complaining about having to live with unpleasant state prosecutors as fellow citizens, he rationalized that the situation elsewhere was probably no better. ${ }^{41}$

As a result of his indictment, Dehmel too searched his soul and admitted his legal problems might be partly deserved. While quickly brushing aside the prosecutor's charges of obscene intent, in his Tagebuch and in private correspondence Dehmel admitted that as an artist, he had let the uncreative "spirit of mere opposition (bloßen Widerspruches) against our times" speak too often and too loudly in his work, ${ }^{42}$ and he reproached himself for "partially 
disfiguring" his art with a faddish "truth-braggadocio" (Wahrheitsrenommage) that was actually less concerned with the truth than with boasting about one's interesting experiences. "So now it seems to me a half-deserved punishment of fate that last week the Munich prosecutor confiscated my second book," he wrote a friend; "I feel, through this indictment,... pushed onto the same bench with people who are alien and repulsive to my entire being. That is my penance." 43

\section{IV}

The third and most curious form of estrangement displayed by censored German authors is internalized alienation. Unlike the radically alienated writers who accepted or even embraced their social alienation as the only path by which they could remain faithful to their calling, authors who internalized their alienation were so profoundly distressed by their isolation from society that they longed for reconciliation with the censor and reintegration into society. To overcome their alienation, these authors internalized the censor's values. Like the ambivalently alienated, they were willing to acknowledge some culpability when confronted by the censor, although their self-criticisms were even more sweeping. Moreover, just as Tonio Kröger had agreed - up to a point - with the policeman's right to carry out his civic duty by interrogating him, the authors who internalized their alienation agreed - up to a point - with the censor's right to censor art. Although they might vehemently object to the censor's judgment of their own work, they acknowledged society's ultimate right to define the boundaries for artistic life. The three authors who best exemplify internalized alienation are Ernst von Wildenbruch (1845-1909), Paul Ernst (1866-1933), and Hermann Sudermann (18571928).

Ernst von Wildenbruch, himself an illegitimate scion of the Prussian royal family, was originally much enamored of the Hohenzollerns and the new Reich. To help legitimate the imperial order and deepen nationalist consciousness, he embarked on a cycle of dramas glorifying the Hohenzollerns' historic rise to German supremacy. When, for sensitive diplomatic reasons, Bismarck in 1889 convinced the Kaiser to ban Der Generalfeldoberst, the second work in the cycle ${ }^{44}$ Wildenbruch was outraged. He called the Kaiser's decision "a terrible blow" that "interrupted my life's work and condemned it to death." His personal relation with Wilhelm II and Bismarck soured considerably after this episode, and he freely expressed his resentments toward the monarch and his royal cabinet. Wildenbruch soon abandoned his plans for the rest of the Hohenzollern dramatic cycle, and turned his hand instead to naturalistic social dramas. ${ }^{45}$

Despite his own unhappy experience with it, however, Wildenbruch continued to accept artistic censorship as a legitimate social institution. In 1900, 
after a second drama of his had been banned, ${ }^{46}$ he explicitly reaffirmed the need for some form of state censorship over "immoral" or otherwise harmful art as long as writers and other literary experts were consulted before the decisions were made. "Is theater censorship even necessary and advisable in the present circumstances," Wildenbruch asked?

This question I answer loudly and decisively with 'Yes.' I do so, although I myself have experienced the bitter sorrow that results when a work is banned - when in one blow the hard work of a year or more is destroyed. Drama, and through it, the theater, is a power, and it lies in the nature of things that the state cannot leave uncontrolled any power that operates within the state's sphere. ${ }^{47}$

Paul Ernst was another censored author whose experience left him estranged from the imperial order, at least initially. After he was fined 100 marks in 1891 for publishing an allegedly immoral short story about the horrors of modern urban life, ${ }^{48}$ this young, left-leaning naturalistic journalist became enraged over the hypocrisy of a society that prevented artists from portraying the scandalous social problems everyone knew existed. He also interpreted the judgment against him as proof of Germany's blatant system of class justice, for the presiding judge had told him that if his story had appeared in a middle-class rather than a working-class publication, it would not have been considered objectionable. ${ }^{49}$ But Ernst quickly internalized the censor's reprimand, to a far greater extent than the ambivalently alienated Wedekind or Dehmel had done. He claims in his memoirs that partly as a result of his obscenity conviction, he was overcome by such a powerful feeling of social loneliness (Einsamkeit) that he completely reappraised his moral and political beliefs, which had always run counter to prevailing values. Did he alone, he wondered, really see the truth while everyone else wallowed in error? Was he alone moral and correct, and the rest of society immoral and misguided? Perhaps, Ernst concluded, it was he who was mistaken. He reproached himself for his youthful intellectual arrogance, abandoned both his naturalistic literary efforts and his left-wing political journalism, and returned home to his parents. In subsequent years, his politics and his art became increasingly conservative..$^{50}$

Similarly, the naturalist Hermann Sudermann, after two of his dramas had been banned from public performance in the $1890 \mathrm{~s},{ }^{51}$ voiced his resentments over the indignities writers must suffer in German society. In 1900 Sudermann helped found and lead the Goethebund, a broad-based organization of artists and academics organized to defend intellectual freedom against a proposed new law, the "Lex Heinze," that was to crack down on "obscene" materials and "immoral" art. In his first speech to the organization, Sudermann complained that German writers and intellectuals were tired of being treated like unruly 
"stepchildren of the nation" who were arbitrarily disciplined and shoved hither and yon by the nation's political leadership. Considering their cultural importance, Sudermann continued, German society had not granted writers, artists, and academics the respect and influence they deserved. ${ }^{52}$

But like Ernst, Sudermann also engaged in a novel form of self reproach. In his Goethebund speech, he told the assembled artists and writers that they themselves were largely responsible for their lamentable position vis $a$ vis the conservative political forces seeking to censor and silence them. Their own disagreements and lack of unity had hitherto condemned German intellectuals to political impotence, he charged. Worse yet, too many artists had been caught up in a hyperaesthetic, insular (weltfremde) arrogance; they had turned their backs on the great issues of the times and had cut themselves off from the wider populace. As a result, the artistic and intellectual community had not only underestimated the power and irreconcilable hatred of its reactionary opponents, but some members had flirted and even cooperated with literature's most bitter enemies. ${ }^{53}$ (This last charge, as we shall see, was soon levelled against Sudermann himself.) Was Sudermann in this speech perhaps projecting or transferring onto writers in general some of the self-criticism and vague sense of culpability that individual authors like Wedekind, Dehmel and Ernst experienced after being challenged by the censor? And rather than blaming writer's social isolation on external hostile forces such as the censor, as the radically and ambivalently alienated authors had done, was not Sudermann implying that some of the hostility directed toward German writers was the result of their own self-imposed isolation? This was the same conclusion that Paul Ernst had reached on a more personal level.

And like Wildenbruch, Sudermann too was eager for a censorship in which writers and artists were actively involved. After the public controversy over the proposed Lex Heinze had abated, Sudermann wrote directly to the Berlin Police President to offer the Goethebund's assistance in helping the police with their difficult duty of removing raw, offensive pictures and printed material from the display windows of book and art stores without offending the sensibilities of the aesthetically-educated citizenry. It was in the interest both of the authorities and of those sensitive to good art, Sudermann argued, to insulate the public from contact with all excesses and nuisances. In light of the difficulty of deciding what should be allowed and what was objectionable, Sudermann, on behalf of the Goethebund, offered to assist and advise the police on difficult borderline cases. In the long term, Sudermann suggested the establishment of a board of artists, literary experts, and book and art dealers that would advise the police on questions of censorship. ${ }^{54}$ When news of Sudermann's offer became public, critics denounced him and the Goethebund. Sudermann and his followers did not really oppose the state drawing up a blacklist of banned, unacceptable art, his critics charged - they merely wanted to help decide which works should be on the list. ${ }^{55}$ 
In his famous 1910 essay "Geist und Tat," Thomas Mann's older brother Heinrich compared the political consciousness and engagement of French men of letters to that of German writers. Whereas French literati from Rousseau to Zola have traditionally been bitter enemies of the powers-that-be, he argued, German intellectuals have generally meekly accepted oppressive authority and have frequently openly embraced it. "In Germany,... the abolition of unjust power has found no support. [Here] one thinks more extensively than anywhere else, one thinks to the very end of pure reason, one thinks to Nothingness: meanwhile, it is God's grace and the fist that rules the country." Although a writer, by his very nature, should be a bitter enemy of dumb, blind power, "it is precisely the literary man [in Germany] who has worked for the prettification of the unspiritual, for the sophistical exoneration of the unjust, for his enemy-to-the death: Power." What might account for this strange perversion of the author's calling, the elder Mann asked? Germany's errant literati have many excuses, he answered, but "above all they have one in the enormous distance that has arisen and that now separates ...German intellectuals from the people." Mann chastised the German intelligentsia for doing nothing to reduce their social isolation:

The time has come, and honor demands, that now, finally, finally, they fulfill the demands of the Geist in this country, too, that they become agitators and ally themselves with the people against Power.... He who exercises might and authority must be our enemy. An intellectual who sides with the ruling caste commits treason against the Geist. ${ }^{56}$

The cases of Panizza, Conradi, Wedekind, Dehmel, Wildenbruch, Ernst, and Sudermann discussed above illustrate just how close and enormously complex was the relationship, pointed out by both Thomas and Heinrich Mann, between German writers' social isolation, their sense of the artist's calling, and their strange, even perverse response to oppressive power. And they make clear as well just how unwilling or unable pre-war German authors, even those who had personally been affected by oppressive state power, were to heed Heinrich Mann's call for a socially-integrated and politically engaged German intelligentsia.

As a result of their encounters with censorship, these authors all experienced some degree of estrangement from imperial Germany, and all had to confront the problem of the writer's social isolation. The radically alienated authors blamed their isolation on a hostile society and/or state that forced artists into the role of outcast or outlaw. Because they were convinced it ostracized and 
victimized artists like themselves, these authors decisively repudiated German society. The ambivalently alienated authors also rebuked their nation for its belittlement and maltreatment of artists; at the same time, however, they believed that their conflicts with the censor could be partly traced to their own shortcomings as writers, to the maladroit way they sometimes exercised their craft. The social or political criticism they voiced was thus tempered and supplemented by a Selbstkritik. Authors who internalized their alienation were more self-critical still, going so far as to imply that writers' isolation in Germany might be as much self-imposed as it was a result of some national antipathy toward art.

Far from lamenting their social and political isolation, radically alienated authors seemed almost to exult in it. For they concluded that modern writers could fulfill their mission only by withdrawing from bourgeois society, by remaining absolutely free from the dictates and constraints it continually sought to impose. To them, artistic integrity was possible only outside society. Ambivalently alienated authors, although feeling that the society and/or the state of imperial Germany thwarted artists from freely and fully exercising their craft, were at the same time unwilling either to sever completely their social ties or to sacrifice their artistic independence to society's dictates. They were thus torn between the seemingly irreconcilable demands of artistic integrity and social integration. Like Tonio Kröger, they accepted with resignation their isolation as the fate of the writer in the modern world. Authors who internalized their alienation wished to overcome their social isolation and believed it was possible to reconcile the artist's calling with society's norms. If artists were integrated into the structures of power, if artists became "insiders" who helped the state define and enforce the socially acceptable limits of artistic activity i.e., if they assisted the authorities in censorship - then the artificial conflict between art and society would be resolved. For these authors, then, artistic integrity was possible within German society.

If we examine how these alienated authors chose to respond to oppressive social or political conditions, we discover that none translated their sense of alienation into the kind of effective political action that Heinrich Mann advocated. The radically alienated chose either complete withdrawal (Panizza first opted for actual emigration abroad, but eventually returned to what must be called an extreme form of "inner emigration," insanity) or, in Conradi's case, what can perhaps be characterized as a form of passive resistance. The ambivalently alienated Wedekind and Dehmel, by contrast, flirted with emigration but then lapsed into a resigned acceptance of their situation in Germany; moreover, the self-doubts aroused in them by the censors undercut their self-confidence and caused them grudgingly to admit that the authorities might have been partially right. Finally, in internalizing their alienation, Wildenbruch, Ernst, and Sudermann ultimately submitted or acquiesced to the 
censor's power, and two of them even believed that artists should collaborate with the censoring authorities (something which, by the way, Thomas Mann himself did by serving briefly on the Munich police's Zensurbeirat) ${ }^{57}$ Collectively, then, these censored authors chose a wide range of responses to power, from willing collaboration to outright exit, but none chose anything like active rebellion against authority; none became, as $\mathrm{H}$. Mann urged, "agitators allied with the people against Power" (although Panizza came the closest). Indeed, except for Sudermann, whose involvement with the Goethebund was shortlived, none of these authors became politically active as a result of their censorship experience, and those, like Panizza or Conradi, who were driven to the most radical judgements about the powers-that-be, did little or nothing to translate their words into concrete actions.

Heinrich Mann's hope was that German writers would abandon their social isolation and become politically engaged. The experiences of the censored authors reveal just how few pre-war writers were able or willing to do so. For those censored authors who were most eager to overcome their alienation (Wildenbruch, Ernst, Sudermann) were also the ones who were most willing to side with the "enemy" and commit treason against the Geist, while those who were the most bitter, uncompromising enemies of unjust power (Panizza and Conradi) were the ones who seemed almost to revel in their social isolation and who regarded the masses with a certain elitist disdain. Only after the war and the collapse of the imperial order did a new generation of writers begin to heed Mann's call to throw off their alienation and become actively and responsibly involved in social and political issues.

\section{VI}

I do not wish to suggest that only authors who actually experienced censorship in pre-war Germany wrestled with problems of alienation or drew these conclusions about society and power. Other individual experiences and psychological factors clearly played a role in these authors' alienation, and one can point to many other German authors who were not censored but who also exhibited the same kinds of alienation as the censored authors discussed above. But even with some of the non-censored authors, censorship played a significant role in their alienation. For example, the novelist and journalist Bernhard Kellermann, addressing his fellow artists in 1919 only weeks after the collapse of the Kaiserreich, reminded them that one of the reasons writers like he had withheld their support (Zuneigung) from the imperial system was because it had denied writers and poets one of their most fundamental rights, freedom. "The capitalistic, imperialistic Germany that just collapsed, with its officials and its police, was unable to awaken any love in the heart of the writer," Kellermann declared. 
Un-spiritual, sterile, reactionary, intolerant, arrogant, and 'infallible,' it contradicted, in all its features, the essential nature of the writer... . Increasingly, and ever more fatefully, the writer became alienated from [that] state. . . In no country was literature and everything spiritual more disdained than in the just-collapsed German authoritarian state....

For literature and writers, this old state did nothing! Less than nothing! Far from fulfilling their demands for freedom, ... it offered unfreedom.

The writer wrote with a shackled hand. Brochures, novellas, novels, were abruptly banned, the performance of dramas forbidden. Whoever overstepped the 'permissible degree' of criticism went to prison... . [The old order] drove any writer who did not share its Weltanschauung out of the public forum. ${ }^{58}$

Free now after centuries of being beaten down, Kellermann called upon his fellow writers to support the new German republic as long as it granted writers complete freedom of expression; henceforth "our conscience and self-criticism shall be our only censors."

Imperial Germany's pervasive censorship system may thus help explain why questions about the writer's calling and his/her troubled relationship with bourgeois society and with the powers-that-be loomed so large there before 1918 - and after. Writers who personally ran afoul of the censors were often forced to confront these questions more personally, more directly, and perhaps earlier than non-censored writers. Yet some non-censored authors, like Kellermann (and Thomas Mann?), also came to recognize that conflicts with state authority, especially in the form of censorship, created a huge distance between many writers and imperial Germany. Because of that distance, few German literati mourned the sudden collapse and disappearance of the imperial order in 1918.

'On the self-consciousness, social isolation, and political withdrawal of German writers and intellectuals, especially during the imperial era, see Hans Reiss, The Writer's Task from Nietzsche to Brecht (Totowa, N.J.: Rowman and Littlefield, 1978); H.W. Rosenhaupt, Der deutsche Dichter um die Jahrhundertwende und seine Abgelöstheit von der Gesellschaft (Berne \& Leipzig: P. Haupt, 1939); Robert Minder, Kultur und Literatur in Deutschland und Frankreich (Frankfurt: Insel Verlag, 1962), 5-43; Fritz Stern, "The Political Consequences of the Unpolitical German," in his Failure of Illiberalism. Essays on the Political Culture of Modern Germany (Chicago \& London:Univ. of Chicago Press, 1975), 3-25; Roy Pascal, From Naturalism to Expressionism. German Literature and Society 1880-1918 (London: Weidenfeld and Nicloson, 1973), 277-314; Gordon A. Craig, 
Germany 1866-1945 (N.Y.: Oxford Univ. Press, 1978), 213-23; R. Hinton Thomas, "German and English Intellectuals - Contrasts and Comparisons," in Upheaval and Continuity. A Century of German History, ed. E. J. Feuchtwanger (Pittsburgh: Univ. of Pittsburgh Press, 1974), 83-100; Paul Kluckhohn, Dichterberuf und bürgerliche Existenz (Tübingen \& Stuttgart: R. Wunderlich, 1949); Robert Anchor, Germany Confronts Modernization. German Culture and Society, 1790-1890 (Lexington, Mass.: D.C. Heath and Co., 1972), 124-26, 144-45; Richard Hamann and Jost Hermand, Epochen deutscher Kultur von 1870 bis zur Gegenwart, 5 vols. (Frankfurt: Fischer Taschenbuch Verlag. 1977), 2:55-64, 3:108-35; and Arnold Hauser, Soziologie der Kunst (Munich: C.H. Beck, 1978), 261-329.

${ }^{2}$ Hermann Hesse, "Der Beruf des Schriftstellers," Wissen und Leben (1910): 48.

${ }^{3}$ Frank Fowell and Frank Palmer, Censorship in England (N.Y.: F. Palmer, 1913), 353; Polizeipräsidium in Berlin, Dritter Verwaltungsbericht des Königlich. Polizeipräsidiums von Berlin für die Jahre 1891-1900 (Berlin, 1902), 373-74.

${ }^{4}$ See, for exam $\rightarrow$ Gary Stark, "The Censorship of Literary Naturalism, 1855-1895: Prussia and Saxony," Central European History, 18, no. 3/4 (Sept./Dec. 1985): 326-43; and Gary Stark, "La police berlinoise et la Freie Volksbühne: Une étude de l'intégration socialiste," Revue d'Histoire du Théâtre, 38, no. 1 (Jan./Mar. 1986): 7-19.

${ }^{5}$ Throughout this essay, I use the term "alienation" primarily in its traditional, preMarxian sense to mean "a withdrawal of support," "a turning away from," "the process of becoming indifferent or hostile to," and "a separation that results in indifference or hostility." Since the publication of Marx's early "Economic and Philosophical Manuscripts" around 1930, the term "alienation" has of course acquired powerful new connotations. This more recent, Marxian concept of alienation is not applicable to most of the authors discussed in this article, and I do not mean to imply that they were alienated in a Marxian sense. Still, in a curious sort of way, some of the authors who experience what I call "ambivalent alienation" and "internalized alienation" do seem to exhibit some of the features of alienation as Marx conceived it: e.g. their own work becomes something of an alien object to them.

"Panizza's short story "Das Verbrechen in Tavistock-Square" (1891) was confiscated in Munich in September 1891 for obscenity, but was released by the court in December. Die unbefleckte Empfängnis der Papste (1893) a satirical anti-Catholic tract, was confiscated in Stuttgart in May 1893 and subsequently banned from the Reich; a similar work, Der teutsche Michel und den römische Papst (1894), was likewise confiscated and banned in 1895. His satirical drama Das Liebeskonzil (1894) was confiscated in Munich in January 1895; Panizza was indicted for blasphemy, convicted in April 1895, and sentenced to 1 year in prison. After his release and resettlement abroad, his $A$ bschied von München: Ein Handschlag (1897), a bitter denunciation of Munich and its authorities, was confiscated there for lèse majesté and a warrant was issued for Panizza's arrest. A second anti-German work, Parisjana: Deutsche Verse (1899) was also confiscated for lèse majesté in January 1900, and a second warrant was issued for the author's arrest. When Panizza returned to Munich and was declared mentally incompetent, the charges were dropped. On Panizza's life and literary works, see Peter D. G. Brown, Oskar Panizza. His Life and Works, American University Studies, Series I: Germanic Languages and Literatures, vol. 27 (N.Y., Frankfurt, Berne: Peter Lang, 1983), and Michael Bauer, Oskar Panizza. Ein literarisches Porträt (Munich: Carl Hanser, 1984). Peter Jelavich's Munich and Theatrical Modernism. Politics, Playwriting, and Performance, 1890-1914 
(Cambridge, Mass.: Harvard Univ. Press, 1985), 54-74, and his "The Censorship of Literary Naturalism, 1890-1895: Bavaria," Central European History, 18, nr. 3/4 (Sept./ Dec. 1985): 344-59 also contain excellent accounts and analyses of Panizza's conflicts with the Bavarian authorities.

${ }^{7}$ Oskar Panizza, Genie und Wahnsinn (Munich: M. Poessl, 1891); and Oskar Panizza, Der Illusionismus und die Rettung der Persönlichkeit: Skizze einer Weltanschauung (Leipzig: Wilhelm Friedrich, 1895). See also the discussions in Brown, Panizza. Life and Work. 23, 39-41; and Bauer, Panizza, 10, 39-51, 132, 168, 193-94.

${ }^{8 n}$ Vorrede" to Das Liebeskonzil, 3d ed. (Zurich: J. Schabelitz, 1897), quoted in Ludwig Leiss, Kunst im Konflikt. Kunst und Künstler im Widerstreit mit der 'Obrigkeit' (Berlin: De Gruyter, 1971), 139.

${ }^{9}$ Dialog im Geiste Huttens (written during Panizza's imprisonment, 1895-96; published in 1897), quoted in Oskar Panizza, Das Liebeskonzil and andere Schriften, ed. and introduction by Hans Prescher (Neuwied: Luchterhand Verlag, 1964), 196; and Oskar Panizza, Psichopatia Criminalis (Zurich: J. Schabelitz, 1898). Also Walter Rösler, "Ein Bißchen Gefängnis und ein bißchen Irrenhaus. Der Fall Oskar Panizza," Sinn und Form, 32, H.4 (Jul/Aug 1980): 840-55.

${ }_{10}^{10}$ anizza, Ein Jahr Gefängnis. Mein Tagebuch aus Amberg, quoted in Prescher, Liebeskonzil und andere Schriften, 172-73. This diary, composed 1895-96, was never published during Panizza's lifetime.

"Panizza, Dialog im Geiste Huttens, in Prescher, Liebeskonzil und andere Schriften, 197.

${ }^{12}$ Jelavich, Munich and Theatrical Modernism, 41.

${ }^{13}$ Brown, Panizza. Life and Works. 47-51; Bauer, Panizza, 189-90.

${ }^{14}$ Oskar Panizza, Meine Verteidigung im Sachen "Das Liebeskonzil" (Zurich: J. Schabelitz, 1895), 26.

${ }^{15}$ Panizza, Dialog im Geiste Huttens, in Prescher, Liebeskonzil und andere Schriften, 196. ${ }^{16}$ Panizza to Max Halbe, 15 July 1896, in Stadtbibliothek Munich, Halbe Archiv; see also Brown, Panizza. Life and Works, 50-51 and Prescher, Liebeskonzil und andere Schriften, 166-67.

${ }^{17}$ Entry in Panizza's notebook, quoted in Bauer, Panizza, 194.

${ }^{18}$ Oskar Panizza, Parisjana. Deutsche Verse aus Paris (Zurich: J. Schabelitz, 1899). See also Brown, Panizza. Life and Works, 100-01.

${ }^{19}$ Panizza, Parisjana, nr. 1; and Brown, Panizza. Life and Works, 57-59, 97-105.

${ }^{20}$ Bauer, Panizza, 196, 220; Brown, Panizza. Life and Works, 97-105.

${ }^{21}$ Bauer, Panizza, 36-37.

${ }^{22}$ Bauer, Panizza, 211-16, and Brown, Panizza. Life and Works, 58.

${ }^{23}$ Adam Mensch (1889), was confiscated by Leipzig authorities in July 1889 , and Conradi was indicted for obscenity and blasphemy. Conradi died in March 1890 before his case went to trial. In June 1890 , the court ruled the novel was obscene and blasphemous and ordered it destroyed. On the so-called "Leipzig Realist Trial," where Conradi and two other authors, Conrad Alberti and Wilhelm Walloth, were charged with obscenity and/or blasphemy, see: Conrad Alberti, "Der Realismus vor Gericht. Nach dem stenographischen Bericht über die Verhandlungen am 23., 26., und 27. Juni 1890 vor der Strafkammer I des Königlichen Landesgerichts zu Leipzig gegen Conrad Alberti, Hermann Conradi, Willi Walloth und deren Verleger," Die Gesellschaft, 6 (Aug. 1890): 1141-232; Heinrich Houben, Verbotene Literatur von der klassischen Zeit bis zur 
Gegenwart: Ein Kritisch-historisches Lexikon über verbotene Bücher, Zeitschriften und Theaterstücke, Schriftsteller und Verleger, 2 vols. (Hildesheim: G. Olms, 1965), 1:10-13, 106; and Gerhard Schulz, "Naturalismus und Zensur," in Naturalismus: Bürgerliche Dichtung und soziales Engagement, ed. Helmut Scheuer (Stuttgart: W. Kohlhammer, 1974), 96-102.

${ }^{24}$ Hermann Conradi, “Gedanken über Kunst, Künstler, Künstlertum," sections iv-vi, in: Hermann Conradis Gesammelte Schriften, ed. Paul Ssymank and G. W. Peters, 3 vols. (Munich: Georg Müller, 1911-12), 1:240-41.

${ }^{25}$ Paul Ssymank, "Leben Hermann Conradis," in: Ssymank \& Peters, Conradis Gesammelte Schriften, 1:ccx, ccxvii.

${ }^{26}$ Letter of 3 December 1889, quoted in Ssymank, "Leben Conradis," 1:ccxvii.

${ }^{27}$ Ssymank, "Leben Conradis," 1:ccxvi-ccxvii.

${ }^{28}$ Wedekind's "Im heiligen Land," a satirical poem that appeared in the October 1898 issue of Simplicissimus, was immediately confiscated in Leipzig for lèse majesté and a warrant was issued for Wedekind's arrest. Wedekind fled first to Switzerland, then to France, but returned to Germany in June 1899 and was sentenced to 7 months imprisonment.

${ }^{29}$ His drama Die Büchse der Pandora (1904) was confiscated in Berlin in July 1904 and Wedekind was indicted for obscenity. Although he was eventually acquitted, a court ruled the work obscene in January 1906 and ordered all printed copies destroyed. In February 1906, Munich authorities confiscated Wedekind's drama Totentanz (1905) and indicted him for obscenity, but charges were later dropped and the text was released. ${ }^{30}$ Numerous cities banned public performances of his famous Frühlingserwachen (1891) until 1906 on grounds of obscenity; in Munich, Lulu (1903) was banned from 19131918, and Simpson, oder Scham und Eifersucht (1914) from 1914-1918 for the same reason; Die Büchse der Pandora, Totentanz, and Schlo $\beta$ Wetterstein (1910) were banned from the public stages of many German cities until 1918, again for obscenity; and public performances of Wedekind's Oaha (1908) were briefly banned in Munich because the play allegedly libelled a living person.

${ }^{31}$ Frank Wedekind, "Torquemada. Zur Psychologie der Zensur," (originally published in Berliner Tageblatt, 17 March 1912), in Frank Wedekind, Gesammelte Werke, 9 vols. (Munich: Georg Müller, 1924), 9:393; and "Vorrede zu 'Oaha', Gesammelte Werke, 9:449-451.

${ }^{32}$ Wedekind, "Vorrede," Gesammelte Werke, 9:451.

${ }^{33}$ Wedekind, "Vorrede," Gesammelte Werke, 9:450.

${ }^{34}$ Wedekind to B. Heine, 12 March 1899, in Frank Wedekind, Gesammelte Briefe, ed. Fritz Strich, 2 vols. (Munich: Georg Müller, 1924), 1:338.

${ }^{35}$ Wedekind to R. Weinhöppel, 22 March 1899, in Wedekind, Gesammelte Briefe, 1:342.

${ }^{36}$ Wedekind to B. Heine, 12 November 1899, in Wedekind, Gesammelte Briefe, 1:316.

${ }^{37}$ Wedekind, "Vorwort" to Die Büchse der Pandora, in Wedekind, Gesammelte Werke (Munich: Georg Müller, 1909), 3:101; Wedekind's comments on the 3d edition of Die Büchse der Pandora, as quoted in Artur Kutscher, Frank Wedekind. Sein Leben und sein Werke, 3 vols. (Munich: Georg Müller, 1922-23), 1:392; and Wedekind to L. Jessner, 30 September 1910, in Wedekind, Gesammelte Briefe, 2:248.

${ }^{38}$ Wedekind, Die Zensur. Theodiziee in drei Szenen (1907), in Frank Wedekind, Werke in drei Bänden, ed. Manfred Hahn (Berlin \& Weimar: Aufbau Verlag, 1969): 1:59-89. Quotation is from scene 2. See also Alan Best, "The Censor Censored: An Approach to Frank Wedekind's 'Die Zensur'," German Life \& Letters, 26, nr. 4 (July 1973): 278-87. 
${ }^{39}$ Dehmel's collection of poems Aber die Liebe (1893) was confiscated by Munich authorities in December 1893; Dehmel was indicted for obscenity and blasphemy, but acquitted in May 1894. In June 1899, the third edition of Aber die Liebe was again confiscated, and Dehmel was indicted for obscenity. He was acquitted in 1900.

${ }^{40}$ Weib und Welt (1896) was confiscated in Berlin in 1897 for obscenity and blasphemy; because the statute of limitations had expired, however, Dehmel was immune from prosecution. Nevertheless, in August 1897 the court ruled the work was obscene and blasphemous, and ordered all copies destroyed.

${ }^{41}$ Dehmel to C. Dehmel, 9 June 1900, and Dehmel to D. von Liliencron, 9 July 1900, in Richard Dehmel, Ausgewählte Briefe aus den Jahren 1893-1902 (Berlin: S. Fischer, 1922), 352, 354.

${ }^{42}$ Gustav Kirstein, Walter Tiemann, E.R. Weiss, eds., Richard Dehmels Tagebuch 18931894 (Leipzig: Dehmel-Gesellschaft, 1921), 78.

${ }^{43}$ Dehmel to H. Thoma, 17 December 1893, in Dehmel, Ausgewählte Briefe, 142.

${ }^{44}$ Der Generalfeldoberst (1889), set during the Thirty Years War, was banned from Berlin theaters in October 1889 on the grounds that it might offend Germany's ally AustriaHungary.

${ }^{45}$ Berthold Litzmann, Ernst von Wildenbruch. Zweiter Band: $1885-1909$ (Berlin: G. Grote, 1916),70-80,105; and Helene Bettelheim-Gabillon, "Wildenbruch und Grillparzer im Spiegel der Zensur," Österreichische Rundschau, 53, nr. 5 (1917): 229-30. See also Kathy Harms, "Writer by Imperial Decree: Ernst von Wildenbruch," in Imperial Germany, ed. Volker Dürr, Kathy Harms, Peter Hayes (Madison, Wisc.: University of Wisconsin Press, 1985), 134-48, esp. 143-44.

${ }^{46}$ Munich police ordered cuts and revisions in his Die Tochter des Erasmus (1899) before they would allow it to be performed publicly, on the grounds that the play contained historical inaccuracies.

${ }^{47}$ "Theater und Zensur. Ein Mahnwort" (1900), in Ernst von Wildenbruch, Gesammelte Werke, ed. Berthold Litzmann (Berlin: G. Grote, 1924), 16:183.

${ }^{48}$ Ernst's "Zum ersten Mal," which appeared in the social-democratic Berliner VolksTribune, in 1891, was confiscated by the Berlin police. Ernst was indicted for obscenity, convicted, and fined 100 marks.

${ }^{49}$ Paul Ernst, Jünglingsjahre (Munich: Georg Müller, 1931), 226; and his article in Berliner Volks-Tribune 5, nr. 17 (1891), reprinted in Karl Kutzbach, "Paul Ernst, Frühste dichterische Arbeiten," Der Wille zur Form, 7 (October 1961): 268.

${ }^{50}$ Ernst, Jünglingsjahre, 227-28.

${ }^{51}$ Berlin police banned Sudermann's Sodoms Ende (1890) from public performance in October 1890 on grounds of obscenity; a court lifted the ban the same month, but on the condition that certain passages be cut before the work was performed. Morituri (1896) was banned in Karlsruhe in January 1897 for defaming the military.

${ }^{52}$ Hermann Sudermann, Drei Reden, gehalten von Hermann Sudermann (Stuttgart: Cotta, 1900), 29. On the "Lex Heinze" and the artistic world's response to it, see Robin Lenman, "Art, Society, and the Law in Wilhelmine Germany: The Lex Heinze," Oxford German Studies, 8 (1973-74): 84-113.

${ }^{53}$ Sudermann, Drei Reden, speech of 25 March 1900, and as reported in Vorwärts, 27 March 1900. 
${ }^{54}$ Undated letter [mid-summer, 1900] to Berlin Police President, in: Deutsches Literaturarchiv, Marbach am Neckar, Cotta Archiv, Nachl. Sud., V 30 Bl. 74. See also Lenman, "Art, Society, and the Law," 110; and Münchener Post, 5 July 1900.

${ }^{55}$ See for example Leo Berg, Gesfesselte Kunst (Berlin: H. Walther, 1901), 11-12.

${ }^{56}$ Heinrich Mann, "Geist und Tat" (written 1910, published in Pan in January 1911), in Essays (Berlin, 1960), 7-14.

${ }^{57}$ Herbert Lehnert and Wulf Segebrecht, "Thomas Mann im Münchener Zensurbeirat (1912/1913). Ein Beitrag zum Verhältnis Thomas Mann zu Frank Wedekind," Jahrbuch der deutschen Schillergesellschaft, 7 (1963): 190-200.

${ }^{58}$ Bernhard Kellermann, "Der Schriftsteller und die deutsche Republik," in: An alle Künstler! (Berlin: W. Simon G.m.b.H., 1919), as reprinted in Weimarer Republik. Manifeste und Dokumente zur deutschen Literatur 1918-1933, ed. Anton Kaes (Stuttgart: J.B. Metzler, 1983), 30-31. 